\title{
Reuse of Ancient Sacred Places in South Ural Region - The Case of Emir Edigey's Grave
}

\section{= Ainur I. Tuzbekov, Ilshat I. Bakhshiev $=$}

The processes of the sacralization of archaeological sites in the South Urals are analysed in the context of Emir Edigey's Grave. The history of the archaeological study of the subject is considered in detail. The works of domestic and foreign authors, electronic publications, and internet video resources are being analysed. Based on personal field research held in May 2015 within the Russian Foundation for Humanities's grant for "Islam in the South Urals geographical information system", the chronology of the formation of the sacred space on the territory of historical and cultural heritage is being restored. In conclusion, the modern sacralization processes taking place on the significant site under consideration and throughout the whole South Urals are characterized.

KEYWORDS: archaeological site, sacralization, saint (awliya), holy place, Emir Edigey's Grave

\section{INTRODUCTION}

Archaeological sites are truly organic elements of the natural and cultural landscapes and up to the present day continue to take a vital place in ritual and spiritual practices of the population of the South Ural region. Moreover, the sites as before endowed with various forms of sacralization and belonged to a group of ritual markers. Information about traditions, legends and rituals associated with the objects of the archaeological heritage is fragmented and not systematized. Some of the aspects of sites sacralization process in South Ural region are covered in books, review articles, and abstracts (Aminev, Yamaeva 2009; Garustovich 2013: 141-142; Savelev 2012: 160-161; Tuzbekov, Bahshiev 2013: 99-102;Kupriyanova 2014: 22-29; Yunusova 2015: 106-115; Shnirelman 2015: 53-65), but the question of formation and transformation of this phenomenon, has not become the subject of a separate study.

Meanwhile, there have been increasing archaeological stories in the formation of new sacred spaces and sites on the territory of the Republic of Bashkortostan in recent years, although the "archaeological" factor of this phenomenon has not been defined, but is only one of its components. Let us give an example. Near Ilchigulovo village (Miyaki district Republic of Bashkortostan) on the top of the high syrt, there is a well-known medieval necropolis - Ilchigulovo IV (Emir Edigey's Grave), the stone walls of which have now become the object of worship and the epicentre of the formation of new sacred spaces. 


\section{ARCHAEOLOGICAL CONTEXT}

The very first archaeological research near Ilchigulovo village was conducted in the $19^{\text {th }}$ century by the anthropologist Maliev. To the southeast of the village, he studied an abandoned cemetery, which people know as nogayskoe. On the burial site, the researcher found several levelled-down burial mounts, some of which were surrounded with stones. According to Maliev's description, there were several Muslim burials sites dating back to the period of the Golden Horde, which had been researched. The author mentions that local Bashkirs prevented further excavations. In 1986 during an archaeological exploration, Garustovich found seven new mounds in the same area, the mounds belonging to various eras, including a necropolis Ilchigulovo IV which residents call as "cemetery of saints" or Edigey's Grave. The burial consisted of two stone lay outs located in 400-500 meter from each other. Round in shape, the lay outs were of stones. During the thorough study of the significant site, it was found that the border №1 was empty, whereas under border №2 there was a burial of a male warrior with traces of chopped wounds.

The buried man was lying on his back, laid on his right side, in a wooden coffin with his head to the west. The skull was turned to the right side and was lying on the temple. Clothes were absent. The scientist referred the burial to late Turkic-speaking nomads (cumans) and dated it to $14^{\text {th }}$ or $15^{\text {th }}$ centuries (Fig.1-2) (Garustovich 1987: 37-39). The researcher attributes the studied complexes with inventory burials of the Ilchigulovo barrow, which had been previously studied by Maliev. Also, he concludes that the studied fences were built of stones taken from the destroyed mounds of the cemetery and were built not earlier than $19^{\text {th }}$ century which later became "a sacred place" (Garustovich 2013: 142).

An indirect confirmation of the data mentioned above is the storyline of the Bashkir epic "Idukay (Edigey) and Muradym (Nurraddin)" dated the end of the $14^{\text {th }}$-beginning the $15^{\text {th }}$ centuries, where the area adjacent to the mountain Narys-Tau is defined as the burial place of the protagonists.

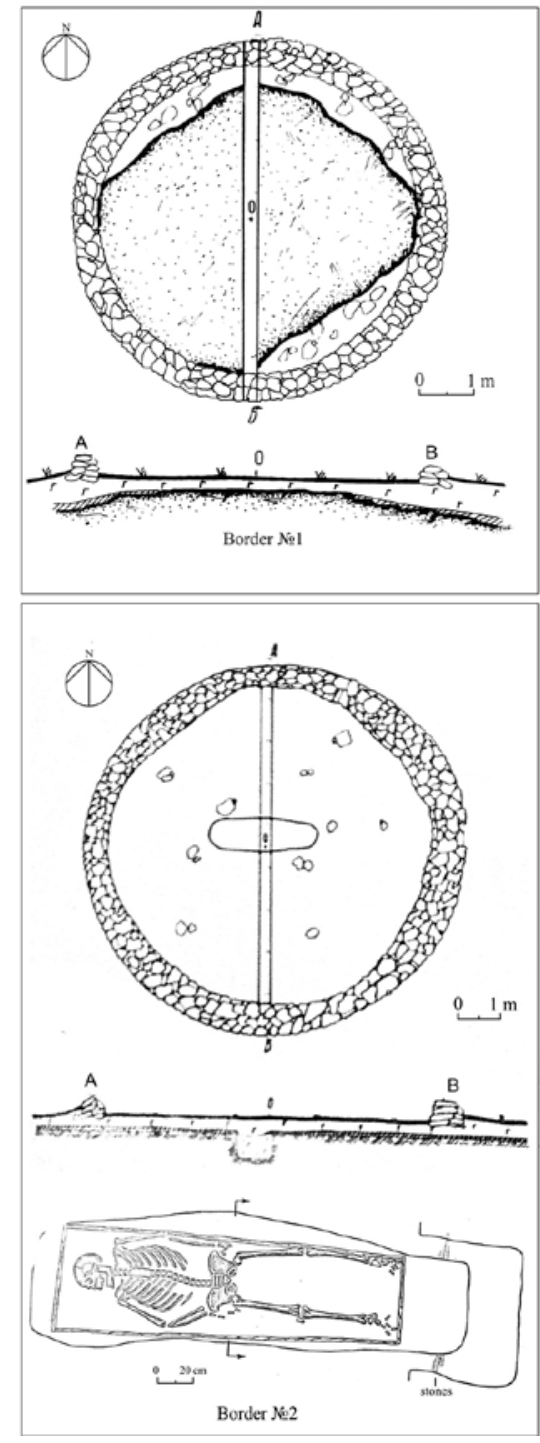

Fig. 1. Borders №1-2 and burial plans of necropolis Ilchigulovo IV (G. Garustovich 1986). 

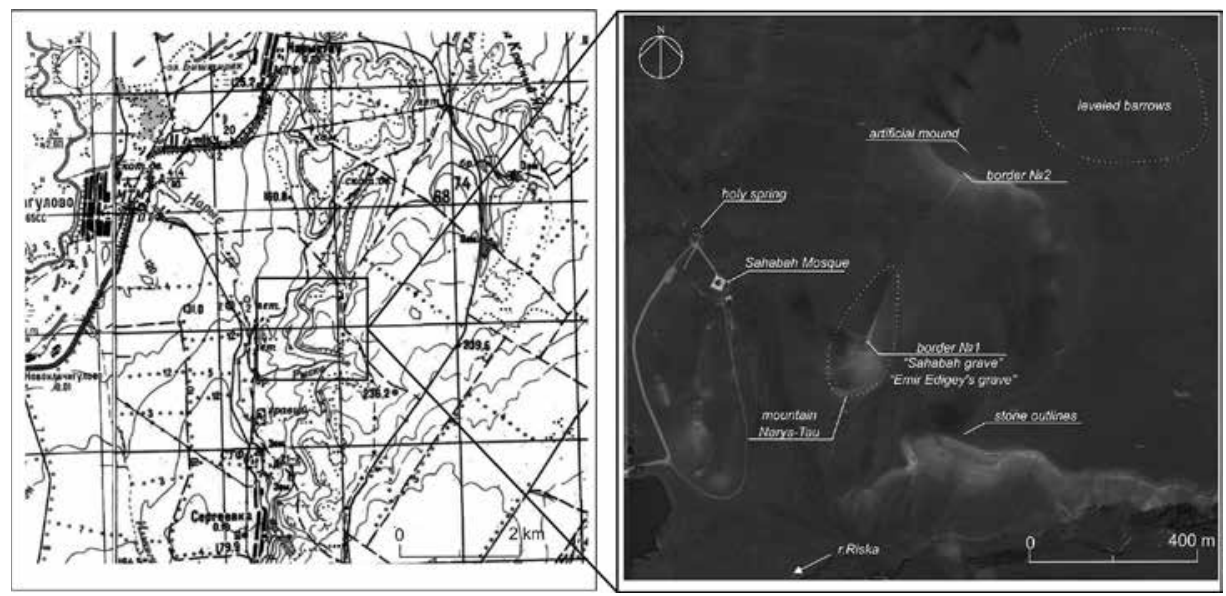

Fig. 2. Necropolis Ilchigulovo IV and new cult objects.

"Ending finally the war

Sword he wiped, his face washed

Once again he stayed at those places

Where the Grave of Idukay (Emir Edigey) and Ynye (Edigey's son Nurraddin)

Was located at Mount Narys" (Zaripov 1999: 186)

According to local residents, as well as data contained in Garustovich's scientific report, a few pilgrims were observed, who would come to the borders and to the "sacred". In subsequent years, the site was probably losing its importance as, according to his observations, in the survey area the "holy spring" was used for cooling milk (Garustovich 1987: 37). There was no information at all on the likely Sahabah (Companions of the Prophet) burial.

How, then, has the structure of the sacred object changed? Let us try to trace the chronology of the events.

\section{THE MYTH CONSTRUCTION}

The beginning of the active search for the graves of the faithful companions of the Prophet in the Volga-Ural region goes back to the last decades of the $20^{\text {th }}$ century. It is associated not only with the growth of religious identity but also with popular abd controversial ideas of Khisam ad-Din Ibn Sharaf ud-Din al-Bulgari Muslim and Taj ad-Din Yalsygul al-Bashkurdimn whose works were sharply criticized by non-traditionalists Mardzhani and Fakhretdinov as well as Usmanov. (Usmanov 1972: 134-166).

The next stage is connected with the visit in 2010 of a Sufi delegation from Bashkortostan, when they visited Sheikh of Sufi Order Naqshbandi Muhammad Nazim Adil al-Haqqani al-Qubrusi (residing in Turkish Republic - Northern Cyprus). During the 
meeting, he was shown some photographs of alleged Sahabah burial sites within the territory of the Republic. Having examined all the photos, sheikh pointed to mountain Narys-Tauas the burial place of the Prophet's Companions (Mehmet Shk 2012).

After the return of the delegation of the Sufis, several articles appeared in some national media about the discovery of Sahabah burial site and an active construction activity started within the cemetery Ilchigulovo IV borders. In 2011, on the ground of border №1, there were build a monument with the names of the two of the Prophet's companions, Zubair ibn Zait and Abdurrakhman ibn Zubair, and a dome-shaped structure, whereas on the ground of border №2 there was only a dome-shaped structure (Fig. 3-4). In 2012, at the foot of the mountain, they started to build a mosque, timed to the monument (Fig.2).

Additional impetus and "legitimation" the object received in 2013 after accompanied by representatives of the local religious leaders' visit of Muhammad (Mehmet) Adil Haqqani al-Qubrusi, the son and power recipient of Muhammad Nasim Haqqani. Mehmet Adil's annual tour (2013 2015) of the "holy places" includes such archaeological sites as stone fences of burial Ilchigulovo IV, Hussain Bek and Bendebike mausoleums, among other. It was the day of his visit to the "holy places" when one could watch more than 1000 pilgrims wishing to honour the shrine.

The zealous pilgrims do not limit themselves to visiting "Sahabah grave" and bathing in the "holy spring". Trying to expand the boundaries of sacred spaces, they include in it more new objects. For example, employees of Institute of Ethnological Studies Ufa Scientific Center, Russian Academy of Sciences during the expedition trip in May 2015 recorded the inclusion into the complex Narys-Tau:

1) An artificial mound formed, most likely as a result of construction work - the so-called "Mound" located 40 meters from the fence to the north-east from border №2, which possibly emerged due to the construction works around border № 2 in 2011. Some pilgrims bypass the object for seven times, assuming that "Awliya" is also buried there.

2) Two stone outlines of a rounded shape with a diameter of $0.5 \mathrm{~m}$ and $0.7 \mathrm{~m}$ composed within 320 meters to the southeast of the border №1 on a cusp-shaped syrt.

Between the stones were detected pieces of thread, material, and crow feathers vertically stuck in the ground. The absence of moss and turf signify that stone throwings appeared relatively recently in the last 5-10 years.

Thus, by this example archaeological site, we can trace one of the models of the formation of contemporary sacred spaces and objects: the design of a completely artificial conceptualization supported by the official Muslim clergy as well as by the authorities at the local level. In this case, this model became the foundation for the promotion of Naqshbandi Sufi Order ideas in the region. 


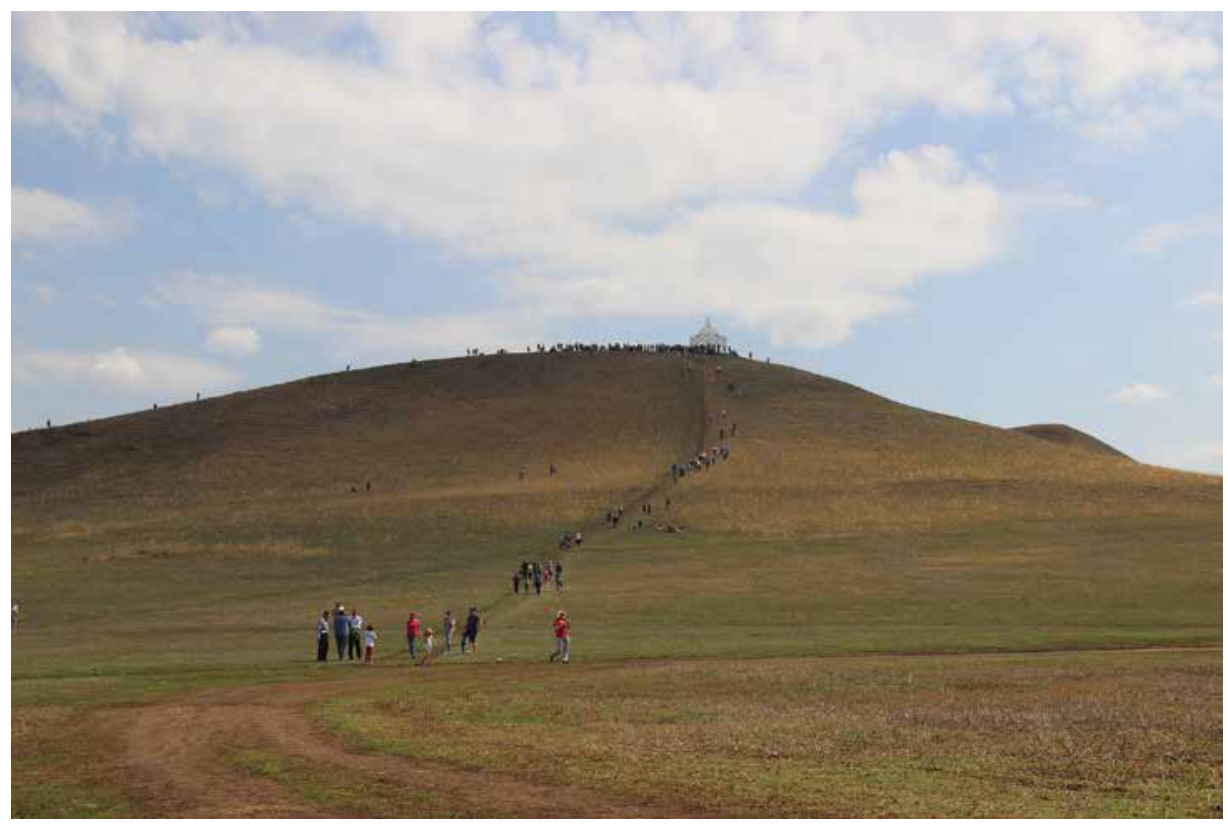

Fig. 3. Border №1 (“Sahaba grave”, “Emir Edigey’s grave”) (photo by A. Tuzbekov, May 2015).

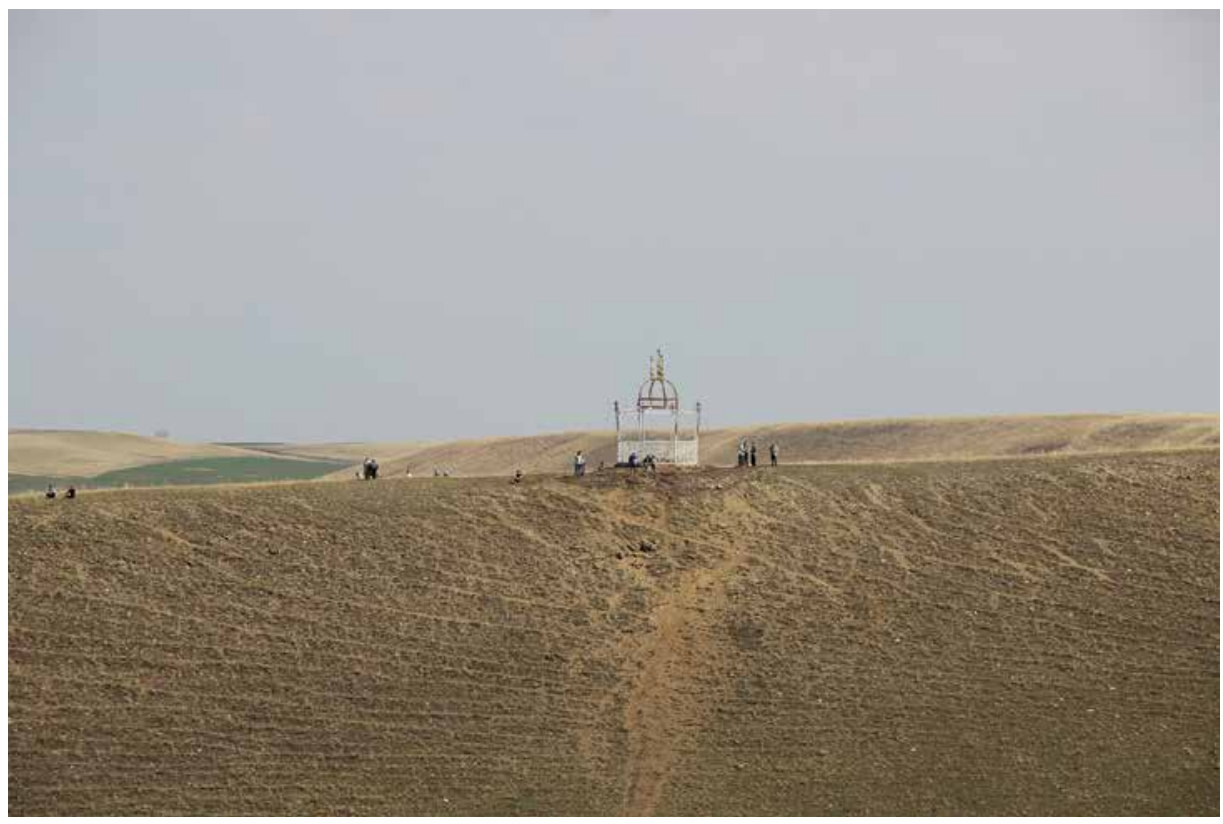

Fig. 4. Border №2 (Awliya Grave) (photo by A. Tuzbekov, May 2015). 


\section{CONCLUSION}

Today, there are more than hundreds of archaeological sites, in the South Urals exposed to sacralization. Representatives of various religious movements and sects, including prohibited ones, attract their new members using the traditional for Bashkirs worshipping the saints (awliya). This explains the significant increase in "places of worship" generated primarily owing to the relief expressing some burial mounds, stone fences, borders, insulated stones, caves, etc. Most of these spontaneous processes occur in the Urals densely inhabited by Bashkirs.

These observations are not unique and virtually similar examples have been recorded in other regions of Russia, CIS countries (Kazakhstan, Kyrgyzstan), Western Europe, China and others.

This phenomenon, of course, requires further investigation, and the similarity of the processes occurring in the archaeological sites spread all around the world, shows the global crisis of traditional spiritual values, which made people search for new or revive some old religious systems that could provide answers to the challenges of the modern world.

\section{BIBLIOGRAPHY}

Aminev, Z. G.; Yamaeva, 1. A. 2009: Regionalnye osobennosti islama u bashkir. Ufa: Dizayn-Poligraf Servis.

Garustovich, G. N. 1987: Otchet ob arheologicheskih rabotah v Meleuzovskom, Kugarchinskom, Chishminskom, Miyakinskom, Bizhbulyakskom i Zianchurinskom rajonah Bashkirskoj ASSR po otkrytomu listu formy №1 za №№ 406 i 407, v 1986 godu. Ufa: Lichniy arhiv.

Garustovich, G. N. 2013: Osobennosti rasprostraneniya islama sredi bashkir v ehpohu srednevekovya.Ufimskiy arheologicheskiy vestnik 13: 137-143.

Kupriyanova, E.V. 2014: Zapovednik «Arkaim» i problemy populyarizacii arheologii na Yuzhnom Urale. Vestnik Chelyabinskogo gosudarstvennogo universiteta 12 (341): 22-29.

Mehmet Shk, 2012: Svyatoy Sheyh Abdurafik iz Bashkirii (sufizm). Online: http://www.youtube. $\mathrm{com} /$ watch? $\mathrm{v}=\mathrm{SMJHSa} \mathrm{iD}$ _Y (5.6.2015).

Savelev, N. S. 2012: Malye kultovye obekty Yuzhnogo Urala: ot arheologii k ehtnograficheskoy sovremennosti. Dokumenty i materialy po istorii bashkirskogo naroda (s drevnejshih vremen do serediny XVI v.). Ufa: $128-166$.

Shnirelman, V. A. 2015: Konstruirovanie istoricheskogo naslediya sluchay Arkaima. Sibirskie istoricheskie issledovaniya 2: 53-65.

Tuzbekov, A. I.; Bahshiev I. I. 2013: Obekty arheologicheskogo naslediya Bashkirskogo Zauralya v sovremennoy ritualnoy praktike yugo-vostochnyh Bashkir. Islam i gosudarstva $v$ Rossii: Sbornik materialov Mezhdunarodnoj nauchno-prakticheskoj konferencii, posvyashchennoy 225-letiyu Centralnogo duhovnogo upravleniya musulman Rossii - Orenburgskogo magometanskogo duhovnogo sobraniya. Ufa: 99-102.

Usmanov, M. A. 1972: Tatarskie istoricheskie istochniki XVII—XVIII vv.: «Sbornik letopisey», "Daftar-i Chingiz-name», «Tavarih-i Bulgariya». Tatarskie shadzhara. Kazan: Kazanskiy gosudarstvenny universitet. 
Yunusova, A. B. 2015: Mobilizovanniy arhaizm: novye tendencii v tradicionnoy religioznoy praktike pokloneniya bashkirskih musulman. Izvestiya Ufimskogo nauchnogo centra RAN3: 106-115.

Zaripov, N. T. (eds). 1999: Idukay i Muradym. Bashkirskoe narodnoe tvorchestvo. Istoricheskiy ehpos. Ufa: Kitap.

\section{ПОВТОРНАЯ САКРАЛИЗАЦИЯ ДРЕВНИХ СВЯТЫНЬ НА ЮЖНОМ УРАЛЕ (ПРИМЕР МОГИЛЫ ЭМИРА ЕДИГЕЯ)}

АЙНУР И. ТУЗБЕКОВ, ИЛШАТ И. БАХШИЕВ

$\bowtie$

В ходе реализации проекта «Геоинформационная система «Ислам на Южном Урале» исследователями Института этнологических исследований им. Р.Г. Кузеева УФИЦ РАН были изучены и картографированы святые места, почитаемые населением региона. В ходе детального изучения объектов была выявлена тенденция современной актуализации сакральных представлений о ранее известных памятниках. Отдельные личности или религиозные группы в последние годы через СМИ, интернет или социальные сети начали активно распространять информацию о святых местах, их значении и т.д. Зачастую объекты, воспринимаемые населением в прошлом как места захоронения легендарных личностей, духовенства, правителей, воинов, начали преподноситься современникам как могилы святых людей. Одним из таких объектов является могила Едигея (Ильчигулово IV, курганный могильник). В статье подробно рассматривается история археологического изучения объекта. На основе архивных материалов автор устанавливает датировку памятника и его историко-культурную принадлежность. Используя данных собранные в ходе полевых исследований, анализа печатных СМИ и интернет изданий восстанавливается хронология переформатирования объекта историко-культурного наследия в сакральное пространство. В заключении подводятся итоги исследования, характеризуются современные процессы сакрализации, происходящие как на рассмотренном памятнике, так и на всей территории Южного Урала в целом.

Ainur I. Tuzbekov, research fellow R.G. Kuzeev Institute for Ethnological Studies - Subdivision of the Ufa Federal Research Centre of the Russian Academy of Sciences, K. Marx st, 6, Ufa, the Republic of Bashkortostan, Russia, tuzbek.80@mail.ru

Ilshat I. Bakhshiev, research fellow R.G. Kuzeev Institute for Ethnological Studies - Subdivision of the Ufa Federal Research Centre of the Russian Academy of Sciences, K. Marx st, 6, Ufa, the Republic of Bashkortostan, Russia, E-mail: ibahsh@gmail.com 